Division of Geological \& Geophysical Surveys

RAW DATA FILE 2017-2

\title{
U-Pb AND Lu-Hf ISOTOPE, AGE, AND TRACE-ELEMENT DATA FROM ZIRCONS AT FOUR SITES IN THE WESTERN ALASKA RANGE AND TALKEETNA MOUNTAINS, ALASKA
}

\author{
Erin Todd, Andrew Kylander-Clark, Alicja Wypych, Evan Twelker, and Karri R. Sicard
}

$\$ 1.00$

2017

THIS REPORT HAS NOT BEEN REVIEWED FOR TECHNICAL CONTENT

OR FOR CONFORMITY TO THE EDITORIAL STANDARDS OF DGGS

Released by

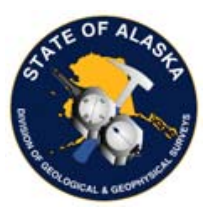

STATE OF ALASKA

DEPARTMENT OF NATURAL RESOURCES

Division of Geological \& Geophysical Surveys

3354 College Road

Fairbanks, Alaska 99709-3707 


\title{
U-Pb AND Lu-Hf ISOTOPE, AGE, AND TRACE-ELEMENT DATA FROM ZIRCONS AT FOUR SITES IN THE WESTERN ALASKA RANGE AND TALKEETNA MOUNTAINS, ALASKA
}

\author{
by \\ Erin Todd ${ }^{1}$, Andrew Kylander-Clark ${ }^{2}$, Alicja Wypych ${ }^{3}$, Evan Twelker ${ }^{3}$, and Karri R. Sicard ${ }^{3}$
}

\section{INTRODUCTION}

This Division of Geological \& Geophysical Surveys (DGGS) Raw Data File presents U-Pb geochronology and Lu-Hf isotopic compositions, age-dating results, and additional trace-elemental composition of zircons from four granitoids sampled during investigations by DGGS geologists in the western Alaska Range and the Talkeetna Mountains. The purpose of the Lu-Hf and U-Pb isotopic study was to better understand the Jurassic through early Tertiary magmatic and tectonic evolution of the Alaska Range and the significance of that magmatism for the formation of metallic mineral deposits. The U-Pb isotopic data also serve to further refine the crystallization age of plutons, which were previously ambiguous in 40Ar/39Ar geochronology studies (for example, Gamble and others, 2013; Benowitz and others, 2015).

The 2013 Styx River geologic mapping project in the Lime Hills C-1 Quadrangle targeted an area hosting multiple overlapping plutonic and volcanic rocks of Late Cretaceous to Tertiary age. This area has received sustained interest from exploration companies evaluating porphyry copper-gold-molybdenum and reduced intrusion-related gold systems. Two samples in this report (13DR046A and 13LF049A) come from an area that was previously mapped as the Merrill Pass pluton based on ca. 35 to $42 \mathrm{Ma} \mathrm{K}-\mathrm{Ar}$ and ${ }^{40} \mathrm{Ar} /{ }^{\beta 9} \mathrm{Ar}$ ages (Gamble and others, 2013; Reed and Lanphere, 1972). Disparate Hf isotopic compositions from the two similar-aged samples indicate varying contributions of crustal- and mantle-derived components.

The 2014 Talkeetna Mountains geologic mapping project was part of a multi-year effort to examine the mineral potential of the less-explored portions of the western Wrangellia terrane. Recent exploration activity has targeted nickel, copper, and platinum-group-bearing mafic-ultramafic complexes. However, there is additional potential for intrusion-related copper and gold mineralization. One of the new Talkeetna Mountains samples (14LL220) establishes a Late Jurassic crystallization age for a pluton previously mapped as Tertiary to Cretaceous (Csejtey and others, 1978). The other sample (14AW266) confirms a Paleocene crystallization age for granitic intrusions in the central Talkeetna Mountains. Both samples have Hf isotopic composition consistent with typical oceanic basalts, indicating primarily mantle sources for both rocks.

The analytical data tables associated with this report are available in digital format as comma-separated value (CSV) files. Additional details about the organization of information are noted in the accompanying metadata file. All files can be downloaded from the DGGS website (http://doi.org/10.14509/29717).

\section{SAMPLE COLLECTION TECHNIQUES}

Fresh, unweathered samples from bedrock outcrops were collected by DGGS field geologists. Sample location coordinates (table 1; WGS84 datum) were obtained using handheld Trimble Juno T5 GPS units, which have a typical reported accuracy of about $10 \mathrm{~m}$. To avoid sending altered minerals for analysis, the zircon separates were further checked using binocular and optical microscopes.

\footnotetext{
${ }^{1}$ U.S. Geological Survey, Alaska Science Center, 4210 University Drive, Anchorage, AK 99508-4626

2 University of California Santa Barbara, Santa Barbara, CA 93106; kylander@geol.ucsb.edu

${ }^{3}$ Alaska Division of Geological \& Geophysical Surveys, 3354 College Road, Fairbanks, AK 99709-3707
} 


\section{ANALYTICAL METHODS}

$\mathrm{Hf}$ isotopes, $\mathrm{U}-\mathrm{Pb}$ ratios, and trace-element compositions for all zircons were measured simultaneously at the University of California, Santa Barbara (UCSB) by laser ablation split-stream (LASS; Kylander-Clark and others, 2013) analysis using the Photon Machines Analyte $193 \mathrm{~nm}$ excimer laser. Spot sizes and laser run conditions are specified in the summary analytical table provided in the digital data. The laser was fired twice to remove surface contamination (primarily common $\mathrm{Pb}$ ), and this material was allowed to wash out for 40 seconds. $\mathrm{Hf}(\mathrm{and} \mathrm{Lu})$ isotopes were measured using the Nu Plasma High-Resolution Multi-Collector Inductively Coupled Plasma Mass Spectrometer (HR MC-ICP-MS). U-Pb isotope ratios and trace-element compositions were measured using an Agilent 7700x quadrupole ICP-MS. For two of the four samples (14AW266 and 14LL220), quadrupole U-Pb ages had anomalously high degrees of scatter during the LASS session, so values reported here were measured in a second session on the $\mathrm{Nu}$ Plasma HR MC-ICP-MS using the same zircons, with smaller spot sizes $(20 \mu \mathrm{m})$ adjacent to spots on which Hf isotopes and trace elements were originally measured. All raw mass spectrometry data acquired during laser ablation was processed using Iolite (version 2.5; Woodhead and Hergt, 2005; Woodhead and others, 2007; Paton and others, 2010; 2011).

Analyses of sample unknowns were bracketed by analyses of the zircon reference materials (RM) 91500 and Mud Tank; 91500 was used as the primary $\mathrm{RM}$ for $\mathrm{U}-\mathrm{Pb}$ geochronology and trace-element analyses. Mud Tank $\left({ }^{176} \mathrm{Hf} /{ }^{177} \mathrm{Hf}=0.282505 \pm 0.000004, \mathrm{MSWD}=0.626 ; \mathrm{n}=331\right)$ was used as the primary RM for Hf isotopes (no correction was applied because measured values were in agreement with accepted ratios; ${ }^{176} \mathrm{Hf} /{ }^{177} \mathrm{Hf}=0.282507$; Woodhead and Hergt, 2005). Additional zircon RM GJ-1 (U-Pb age $=606.7 \pm 17.9, \mathrm{MSWD}=2.904 ;{ }^{176} \mathrm{Hf} /{ }^{177} \mathrm{Hf}$ $=0.282001 \pm 0.000034, \mathrm{MSWD}=1.928 ; \mathrm{n}=8)$, Plesovice $(\mathrm{U}-\mathrm{Pb}$ age $=337.0 \pm 1.9, \mathrm{MSWD}=0.183$; $176 \mathrm{Hf} / 177 \mathrm{Hf}=0.282494 \pm 0.000004, \mathrm{MSWD}=1.116 ; \mathrm{n}=206)$, and Temora2 $(\mathrm{U}-\mathrm{Pb}$ age $=426.5 \pm 3.5, \mathrm{MSWD}=$ $\left.0.846 ;{ }^{176} \mathrm{Hf} /{ }^{177} \mathrm{Hf}=0.282689 \pm 0.000011, \mathrm{MSWD}=1.331 ; \mathrm{n}=71\right)$ were included as secondary standards to monitor reproducibility. Two-sigma $(2 \sigma)$ analytical uncertainties associated with $\mathrm{U}-\mathrm{Pb}$ ages reported here are better than the approximately 2 percent long-term empirical scatter of ages measured at the UCSB laboratory.

Weighted mean values and uncertainty $(2 \sigma)$ shown in table 1 were calculated using Isoplot 4.15 (Ludwig, 2012). Grains with discordant ages (that is, disagreement between ${ }^{206} \mathrm{~Pb} /{ }^{238} \mathrm{U}$ - and ${ }^{207} \mathrm{~Pb} /{ }^{235} \mathrm{U}$-calculated ages) were omitted from weighted means of all calculated ages, isotope ratios, and measured concentrations ( $\mathrm{U}-\mathrm{Pb}$ age, Hf isotopes, and trace elements). In addition, weighted mean Hf isotope ratios excluded obvious outliers that typically corresponded to zircons where the spot size $(50 \mu \mathrm{m})$ was roughly equal to, or exceeded, zircon grain sizes. Weighted mean trace-element concentrations also excluded zircon grains with anomalous trace-element concentrations where inclusions were suspected to impart non-zircon signal (for example, apatite, ilmenite) on integration of measured trace elements.

Hafnium isotope epsilon $(\varepsilon)$ values and age-corrected isotope values were calculated assuming chondritic ${ }^{176} \mathrm{Hf} /{ }^{177} \mathrm{Hf}$ and ${ }^{176} \mathrm{Lu} /{ }^{177} \mathrm{Hf}$ ratios of 0.282772 and 0.0332 (Blichert-Toft and Albarède, 1997) and a lutetium-176 decay constant of 1.86x10-11 (Scherer and others, 2001). Model ages (tHf-DM), in billions of years, were calculated assuming present-day depleted mantle ${ }^{176} \mathrm{Lu} /{ }^{177} \mathrm{Hf}$ and ${ }^{176} \mathrm{Hf} /{ }^{177} \mathrm{Hf}$ values of 0.0384 and 0.28325 (Griffin and others, 2000).

Equilibrium crystallization temperatures for zircon were calculated using the Ti-in-zircon thermometer, after Ferry and Watson (2007), assuming activity of $\mathrm{SiO}_{2}$ and $\mathrm{TiO}_{2}\left(\mathrm{aSiO}_{2}\right.$ and $\left.\mathrm{aTiO}_{2}\right)$ of 0.7 .

\section{DISCUSSION}

A summary of all $\mathrm{U}-\mathrm{Pb}$ ages, Lu-Hf isotopic data, and trace-element analyses is included in the accompanying data distribution file set, with all ages, isotope, and trace-element data reported with uncertainty at the 2- $\sigma$ level. Trace-element data and $\mathrm{U} / \mathrm{Pb}$ age concordance were used to assess whether each analyzed crystal was homogeneous or possibly contained heterogeneities such as mineral inclusions. For example, zircon from samples 13LF049A and 13DR046A were particularly inclusion-rich (and possibly metamict; figure 1A and 1B), so a small number of the analyzed grains were used in the final calculation of ages and isotope ratio means. In comparison, 
zircon grains from samples 14AW266 and 14LL220 were much larger, with few inclusions (figure 1C and 1D). The rock samples are described below.

\section{DR046A}

Coarse-grained but seriate, leucocratic, xenomorphic granite, with $73 \%$ feldspar and $27 \%$ quartz. Weathered white.

\section{LF049A}

Seriate to medium-grained granite, with miarolitic cavities. The rock has $25 \%$ quartz, $10 \%$ potassium feldspar, $10 \%$ biotite, and $5 \%$ hornblende in fine-grained white goundmass. Quartz is $2-5 \mathrm{~mm}$ in diameter; potassium feldspar averages $5 \mathrm{~mm}$ in length; the same minerals line the miarolitic cavities.

\section{AW266}

Equigranular, medium-grained granitoid, with 1- to 2-mm-diameter anhedral potassium feldspar ( $20 \%$ of rock), 1-mm-long subhedral plagioclase ( $\sim 55 \%$ of rock), 1 - to 2 -mm-diameter anhedral biotite $(\sim 10 \%), 0.5$ - to 1 -mmlong subhedral hornblende $(\sim 10 \%)$ and fine-grained interstitial quartz (no more than $5 \%$ of rock). The potassium feldspar displays resorption textures, with slightly sericitized more calcic-rich cores and recrystallized potassium feldspar rims; the plagioclase displays polysynthetic twinning. The feldspars often display wavy extinction, suggesting high-pressure metamorphism. Feldspar is locally replaced by biotite, which is generally fresh but rarely has slight chloritization, whereas amphibole is typically replaced by chlorite.

\section{LL220}

Seriate, medium- to fine-grained granitoid, with 2- to 3-mm-diameter interstitial quartz (37\% of rock), 1 - to 3-mmlong subhedral potassium feldspar ( $25 \%$ of rock), 1 - to 2 -mm-long subhedral plagioclase ( $30 \%$ of rock), 0.5 - to 1 mm-diameter anhedral biotite (no more than 5\% of rock), and 0.5 - to 1 -mm-diameter subhedral to euhedral hornblende (2-3\% of rock). The potassium feldspar crystals are oscillatory zoned; plagioclase is partially sericitized. Biotite is fragmental, often chloritized, and hosts oxide inclusions. Amphibole is twinned and occasionally chloritized and resorbed (possibly representing two generations of amphibole). Accessory epidote is often associated with the mafic minerals. 


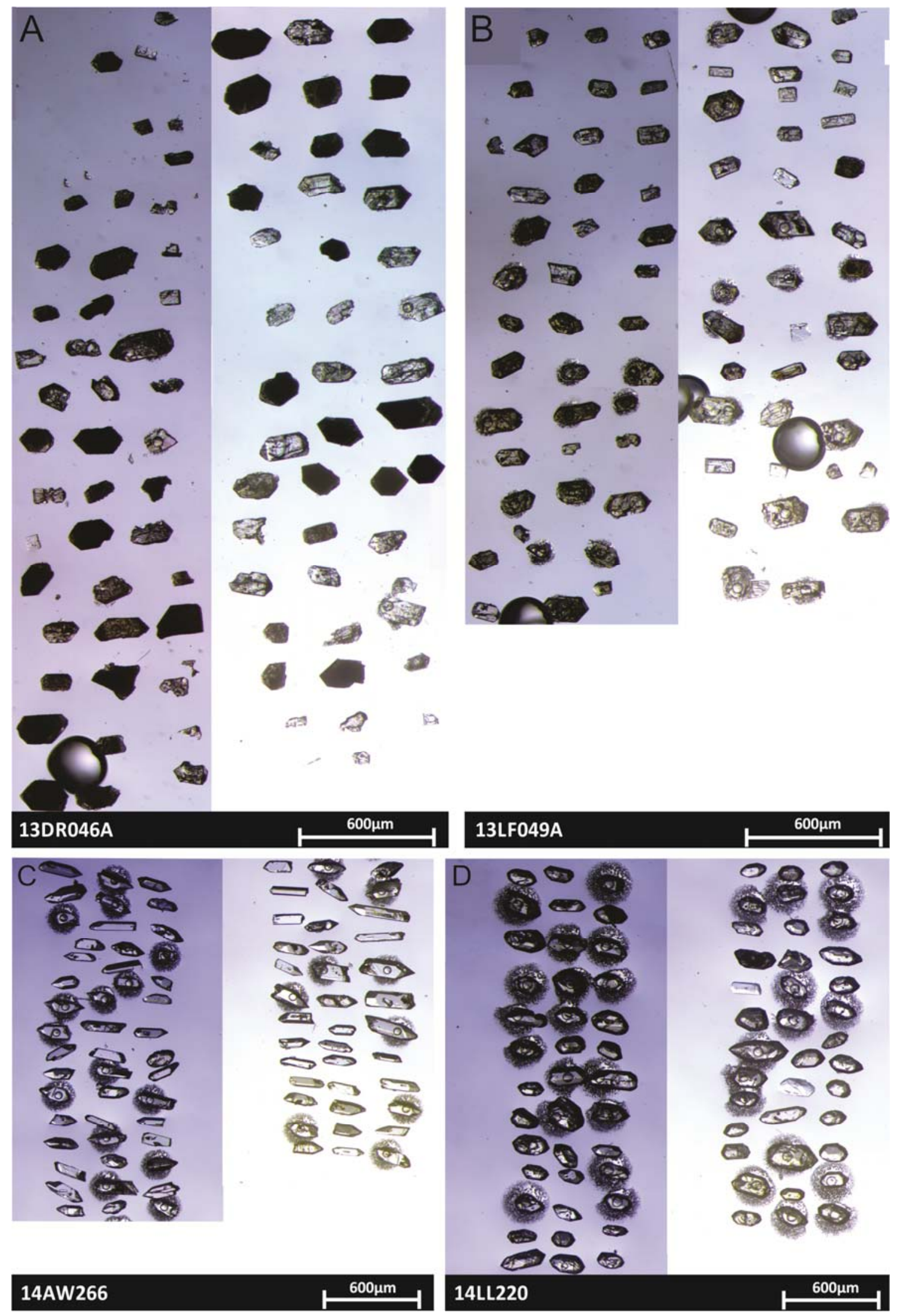

Figure 1. Photomicrograph of analyzed zircon grains from samples (A) 13DR046A, (B) 13LF049A, (C) 14AW266, and (D) 14LL220. 
13LF049A

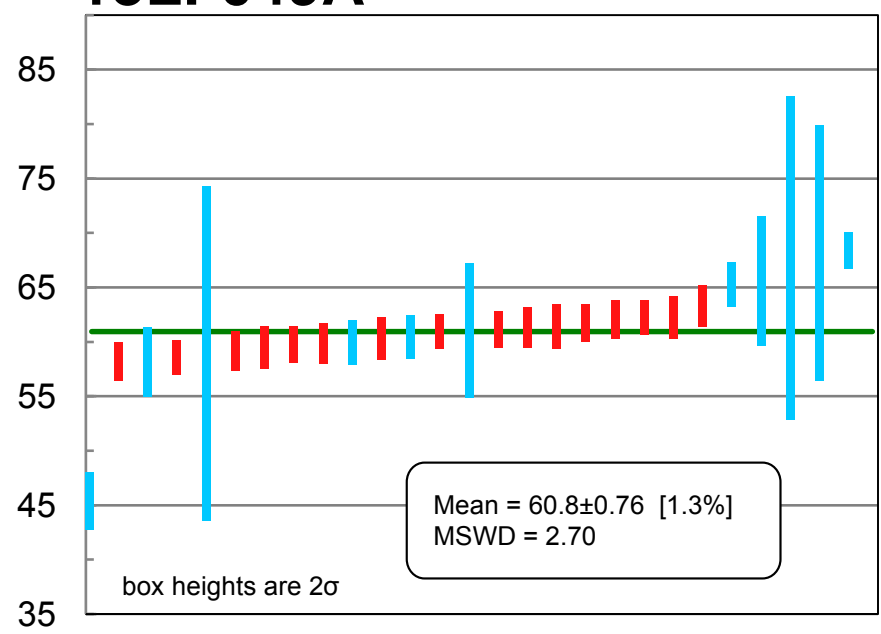

13DR046A

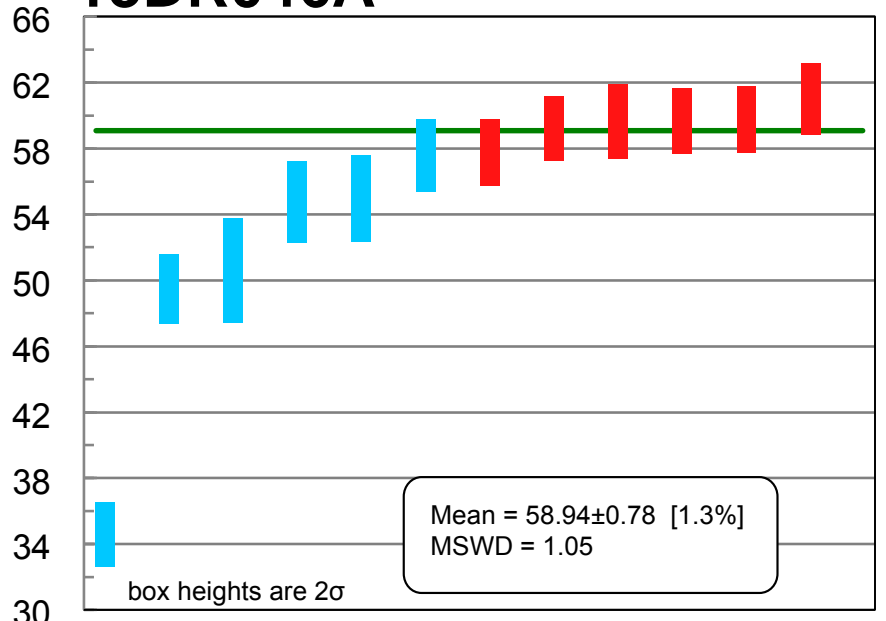

14AW266

68

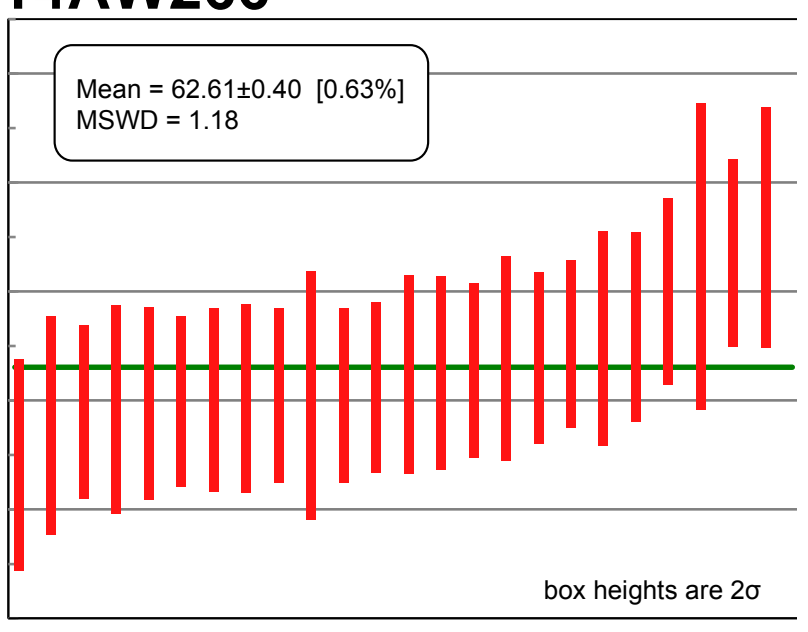

14LL220

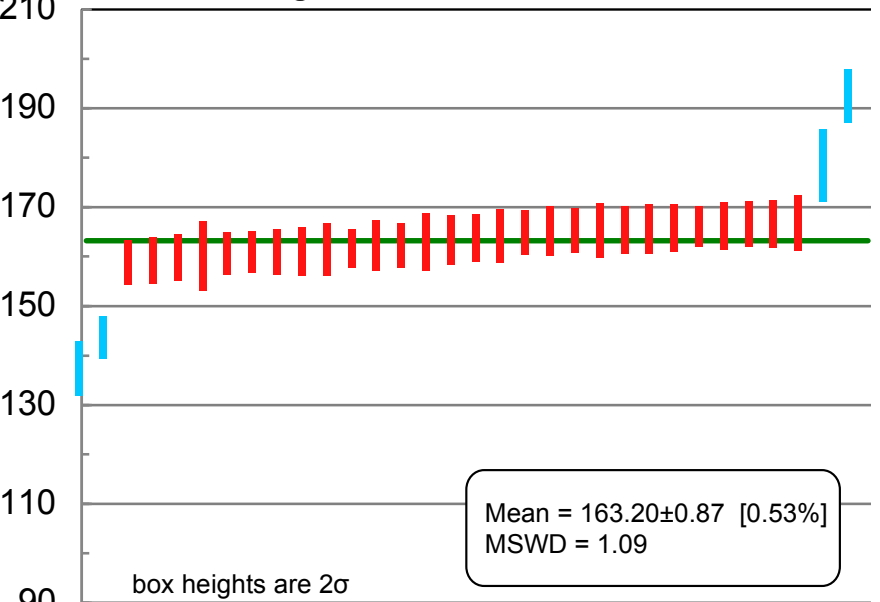

Figure 2. Plots of weighted mean zircon U-Pb ages. Red bars indicate zircon ages, at 2-sigma bar height, contributing to weighted means. Blue bars indicate zircon analyses excluded from the weighted mean (that is, omitted as statistical outliers, or because they have discordant U-Pb ages).

Table 1. Summary of the age and isotopic composition of analyzed zircon samples.

\begin{tabular}{|c|c|c|c|c|c|c|c|}
\hline \multirow[b]{2}{*}{ Sample } & \multirow[b]{2}{*}{ Longitude } & \multirow[b]{2}{*}{ Latitude } & \multirow{2}{*}{$\begin{array}{c}{ }^{238} \mathrm{U} /{ }^{206} \mathrm{~Pb} \\
\text { best age } \\
\text { [Ma] }\end{array}$} & \multicolumn{2}{|c|}{ measured } & \multicolumn{2}{|c|}{ age corrected $(T)$} \\
\hline & & & & ${ }^{176} \mathrm{Hf} /{ }^{177} \mathrm{Hf}$ & $\varepsilon H f$ & ${ }^{176} \mathrm{Hf} /{ }^{177} \mathrm{Hf}(\mathrm{T})$ & $\varepsilon H f(T)$ \\
\hline 13LF049A & -153.2286 & 61.6429 & $\begin{array}{c}60.79 \pm \\
0.68\end{array}$ & $\begin{array}{c}0.283082 \pm \\
0.000023\end{array}$ & $\begin{array}{c}+10.96 \pm \\
0.81\end{array}$ & 0.283079 & +9.24 \\
\hline 13DR046A & -153.1484 & 61.6536 & $\begin{array}{c}58.94 \pm \\
0.78\end{array}$ & $\begin{array}{c}0.282643 \pm \\
0.000053\end{array}$ & $\begin{array}{c}-4.56 \pm \\
1.87\end{array}$ & 0.282639 & -6.32 \\
\hline 14AW266 & -148.8746 & 62.7350 & $\begin{array}{c}62.61 \pm \\
0.40\end{array}$ & $\begin{array}{l}0.28307 \pm \\
0.000016\end{array}$ & $\begin{array}{c}+10.54 \pm \\
0.57\end{array}$ & 0.283068 & +8.86 \\
\hline 14LL220 & -148.5107 & 62.5699 & $\begin{array}{c}163.2 \pm \\
0.87\end{array}$ & $\begin{array}{c}0.282965 \pm \\
0.000015\end{array}$ & $\begin{array}{c}+6.83 \pm \\
0.53\end{array}$ & 0.282958 & +7.46 \\
\hline
\end{tabular}




\section{ACKNOWLEDGMENTS}

Processing of the isotopic analyses in this report was funded through a cooperative partnership between the U.S. Geological Survey and the Alaska Division of Geological \& Geophysical Surveys. The Styx mineral assessment project was conducted under the Alaska Airborne Geophysical/Geological Mineral Inventory Program (AGGMI), funded by the Alaska State Legislature and managed by DGGS. The Talkeetna Mountains project was jointly funded by the State of Alaska's Strategic and Critical Minerals Assessment program (part of AGGMI) and the USGS National Cooperative Geologic Mapping Program, STATEMAP component, under award number G14AC00167 for 2014. We thank Jamey Jones (USGS Anchorage) and Chris Holm-Denoma (USGS Denver) for their suggestions and edits. The views and conclusions contained in this document are those of the authors and should not be interpreted as necessarily representing the official policies, either expressed or implied, of the U.S. Government.

\section{REFERENCES CITED}

Benowitz, J.A., Layer, P.W., Wypych, Alicja, and Twelker, Evan, $2015,{ }^{40} \mathrm{Ar} /{ }^{39} \mathrm{Ar}$ data from the Talkeetna Mountains C-4 Quadrangle and adjoining areas, central Alaska: Alaska Division of Geological \& Geophysical Surveys Raw Data File 2015-10, 19 p. http://doi.org/10.14509/29454

Blichert-Toft, Janne, and Albarède, Francis, 1997, The Lu-Hf isotope geochemistry of chondrites and the evolution of the mantle-crust system: Earth and Planetary Science Letters, v. 148, no. 1, p. 243-258. http://doi.org/10.1016/S0012-821X(97)00040-X

Csejtey, Bela, Jr., Nelson, W.H., Jones, D.L., Silberling, N.J., Dean, R.M., Morris, M.S., Lanphere, M.A., Smith, J.G., and Silberman, M.L., 1978, Reconnaissance geologic map and geochronology, Talkeetna Mountains Quadrangle, northern part of Anchorage Quadrangle, and southwest corner of Healy Quadrangle, Alaska: U.S. Geological Survey Open-File Report 78-558-A, 60 p., 1 sheet, scale 1:250,000. https://pubs.er.usgs.gov/publication/ofr78558A

Ferry, J.M., and Watson, E.B., 2007, New thermodynamic models and revised calibrations for the Ti-in-zircon and Zr-in-rutile thermometers: Contributions to Mineralogy and Petrology, v. 154, no. 4, p. 429-437, http://doi.org/10.1007/s00410-007-0201-0

Gamble, B.M., Richter, D.H., and Lanphere, M.A., 2013, Geologic map of the east half of the Lime Hills 1:250,000-scale quadrangle, Alaska: U.S. Geological Survey Open-File Report 2013-1090, 1 sheet, scale 1:2,500,000. https://pubs.usgs.gov/of/2013/1090/

Griffin, W.L., Pearson, N.J., and Belousova, E.A., 2000, The Hf isotope composition of cratonic mantle-LAMMC-ICPMS analysis of zircon megacrysts in kimberlites: Geochimica et Cosmochimica Acta, v. 64, no. 1, p. 133-147. http://doi.org/10.1016/s0016-7037(99)00343-9

Kylander-Clark, A.R.C., Hacker, B.R., and Cottle, J.M., 2013, Laser-ablation split-stream ICP petrochronology: Chemical Geology, v. 345, p. 99-112. http://doi.org/10.1016/j.chemgeo.2013.02.019

Ludwig, K.R., 2012, User's manual for Isoplot 3.75-A geochronological toolkit for Microsoft Excel: Berkeley, CA, Berkeley Geochronology Center Special Publication No. 5 (rev. January 30, 2012). www.bgc.org/isoplot_etc/isoplot/Isoplot3 75-4 15manual.pdf

Paton, Chad, Hellstrom, J.C., Paul, Bence, Woodhead, J.D., and Hergt, J.M., 2011, Iolite-Freeware for the visualisation and processing of mass spectrometer data: Journal of Analytical Atomic Spectrometry, v. 26, p. 2,508-2,518. http://doi.org/10.1039/C1JA10172B

Paton, Chad, Woodhead, J.D., Hellstrom, J.C., Hergt, J.M., Greig, Alan, and Maas, Roland, 2010, Improved laser ablation $\mathrm{U}-\mathrm{Pb}$ zircon geochronology through robust downhole fractionation correction: Geochemistry, Geophysics, Geosystems, v. 11, no. 3, Q0AA06. http://doi.org/10.1029/2009GC002618 
Reed, B.L., and Lanphere, M.A., 1972, Generalized geologic map of the Alaska-Aleutian Range batholith showing potassium-argon ages of the plutonic rocks: U.S. Geological Survey Miscellaneous Field Studies Map 372, 2 sheets. https://pubs.er.usgs.gov/publication/mf372

Scherer, E.E., Münker, Carsten, and Mezger, Klaus, 2001, Calibration of the Lutetium-Hafnium clock: Science, v. 293, no. 5530, p. 683-687. http://doi.org/10.1126/science. 1061372

Woodhead, J.D., Hellstrom, J.C., Hergt, J.M., Greig, Alan, and Maas, Roland, 2007, Isotopic and elemental imaging of geological materials by laser ablation inductively coupled plasma mass spectrometry: Journal of Geostandards and Geoanalytical Research, v. 31, no. 4, p. 331-343. http://doi.org/10.1111/j.1751908X.2007.00104.X

Woodhead, J.D., and Hergt, J.M. 2005, A preliminary appraisal of seven natural zircon reference materials for in situ Hf isotope determination: Geostandards and Geoanalytical Research, v. 29, no. 2, p. 183-195. http://doi.org/10.1111/j.1751-908X.2005.tb00891.X 